\title{
Correction to: Intensification of agriculture in southwestern Germany between the Bronze Age and Medieval period, based on archaeobotanical data from Baden-Württemberg
}

\author{
Gegeensuvd Tserendorj ${ }^{1}$ - Elena Marinova ${ }^{1} \cdot$ Jutta Lechterbeck $^{2} \cdot$ Hermann Behling $^{3} \cdot$ Lucia Wick $^{4} \cdot$ Elske Fischer $^{1}$. \\ Marion Sillmann ${ }^{1} \cdot$ Tanja Märkle $^{1} \cdot$ Manfred Rösch $^{5}$
}

Published online: 13 May 2021

(c) The Author(s) 2021

\section{Correction to: \\ Vegetation History and Archaeobotany (2021) 30:35-46 https://doi.org/10.1007/s00334-020-00814-x}

The article "Intensification of agriculture in southwestern Germany between the Bronze Age and Medieval period, based on archaeobotanical data from Baden-Wurttemberg" written by Gegeensuvd Tserendorj, Elena Marinova, Jutta Lechterbeck, Hermann Behling, Lucia Wick, Elske Fischer, Marion Sillmann, Tanja Märkle and Manfred Rösch was originally published Online First without Open Access. After publication in volume 30, issue 1, page 35-46 the author decided to opt for Open Choice and to make the article an Open Access publication. Therefore, the copyright of the article has been changed to (C) The Author(s) 2021 and the article is forthwith distributed under the terms of the Creative Commons Attribution 4.0 International License,

The original article can be found online at https://doi.org/10.1007/ s00334-020-00814-x.

Gegeensuvd Tserendorj

gegeensuvd.tserendorj@rps.bwl.de

1 Landesamt für Denkmalpflege im Regierungspräsidium Stuttgart, Fischersteig 9, 78343 Gaienhofen-Hemmenhofen, Germany

2 Museum of Archaeology, University of Stavanger, Peder Klows gate 31A, PB 8600 Forus, 4036 Stavanger, Norway

3 Department of Palynology and Climate Dynamics, Albrecht-Von-Haller-Institute for Plant Sciences, Georg-August-University of Göttingen, Untere Karspüle 2, 37073 Göttingen, Germany

4 Dept. Umweltwissenschaften IPNA, Universität Basel, Spalenring 145, 4055 Basel, Switzerland

5 Institut für Ur- Und Frühgeschichte und Vorderasiatische Archäologie, Universität Heidelberg, Sandgasse 7, 69117 Heidelberg, Germany which permits use, sharing, adaptation, distribution and reproduction in any medium or format, as long as you give appropriate credit to the original author(s) and the source, provide a link to the Creative Commons licence, and indicate if changes were made. The images or other third party material in this article are included in the article's Creative Commons licence, unless indicated otherwise in a credit line to the material. If material is not included in the article's Creative Commons licence and your intended use is not permitted by statutory regulation or exceeds the permitted use, you will need to obtain permission directly from the copyright holder. To view a copy of this licence, visit http:// creativecommons.org/licenses/by/4.0/.

The original article has been corrected.

Open Access This article is licensed under a Creative Commons Attribution 4.0 International License, which permits use, sharing, adaptation, distribution and reproduction in any medium or format, as long as you give appropriate credit to the original author(s) and the source, provide a link to the Creative Commons licence, and indicate if changes were made. The images or other third party material in this article are included in the article's Creative Commons licence, unless indicated otherwise in a credit line to the material. If material is not included in the article's Creative Commons licence and your intended use is not permitted by statutory regulation or exceeds the permitted use, you will need to obtain permission directly from the copyright holder. To view a copy of this licence, visit http://creativecommons.org/licenses/by/4.0/.

Publisher's Note Springer Nature remains neutral with regard to jurisdictional claims in published maps and institutional affiliations. 